\title{
Financial Impact of Canadian Bill 198 on Seasoned Equity Offerings by Canadian Firms
}

\author{
By Arturo Rubalcava*
}

This study explores the financial impact of the Canadian Bill 198on seasoned equity offerings by Canadian firms -cross-listed in major U.S. stock exchanges and those listed in the Toronto Stock Exchange only (non-cross-listed). Canadian Bill 198, also called Canadian SOX, became effective in December 2005. It finds the market reaction to all offer announcements is not different between the period 1999-2005 (pre-Bill) and the period 2006-2011 (post-Bill). When distinguishing offers by cross-listed and matched non-cross-listed firms, the market reaction is also not significantly different between the pre-and the post-Bill periods, after conditioning for offer and firm characteristics. On the other hand, when distinguishing offers by underwriting method (marketed underwritten versus bought deals), the market reaction is less positive for marketed underwritten offers than bought deals for the post-Bill period only-mostly for noncross-listed firms. This may explain why marketed underwritten offers have decreased significantly as a choice for underwriting seasoned equity offerings in the last years.

Keywords: Bill 198, Sarbanes-Oxley, Seasoned equity offerings, Cross-listed, Market reaction, bought deals, Marketed underwritten offers

\section{Introduction}

Bill 198 is a Canadian legislation similar to the U.S. Sarbanes-Oxley (SOX) of 2002 focused in increased transparency in financial information of publicly traded companies. After the passage of Sarbanes-Oxley many countries passed similar legislation, for example, U.K., Australia, the European Union, Japan, China, and the Philippines (Rubalcava 2012a). Canadian regulators passed Bill 198 in October 2002 and became effective in December 2005. One important objective of SOX and Bill 198 is to foster improved disclosure by firms to protect investors by major corporate wrongdoing.

The research evidence on the impact of SOX is vast. It finds compliance costs are higher than its benefits - mostly from firms subject to SOX from developed countries with good governance (Bris et al. 2007, Li 2011, Litvak 2007, 2008). Similarly, Canadian firms cross-listed in major U.S. exchanges report negative valuation (Tobin's Q) after the passage of SOX (Amoako-Adu and Baulkaran 2008). On the other hand, limited research on the impact of Bill 198 on public Canadian firms exists. Relevant research include topics such as changes in corporate governance (Ben-Ishai 2008); positive impact on corporate governance and firm efficiency (Bozec et al. 2010); convergence of Canadian corporate governance practices towards the U.S. model (Bozec and Dia 2012), Bozec et al. (2013), changes in corporate social responsibility (Mahoney and

\footnotetext{
${ }^{*}$ Associate Professor (Finance), Faculty of Business Administration, University of Regina, Canada.
} 
Thorne 2014); positive impact on Canadian acquisitions (Hossain, 2013); and negligible impact on the valuation of Canadian non-cross-listed firms (AmoakoAdu and Baulkaran 2008).

According to Eckbo et al. (2007), regulatory changes such as Bill 198 would be an interesting testing ground to analyze its impact on equity issuance costs for Canadian firms. Empirical research shows the market reaction to the announcement of seasoned equity offerings is on average around $-2 \%$ of firm value - representing an important indirect issue cost for traded companies. Following their suggestion, this is the first study that examines the effects of Bill 198 on the market reaction of seasoned equity offerings (SEOs) for Canadian firms -cross-listed in major U.S. exchanges and those listed in the TSX only (non-cross-listed). It also distinguishes by underwriting method -bought deals and marketed underwritten offers-, for cross-listed and non-cross-listed firms. Rubalcava (2012b) shows the market reaction to SEO announcements of Canadian cross-listed firms -which are subject to SOX-, is more negative after the passage of SOX. By including Canadian non-cross-listing firms, bought deals and marketed underwritten offers, this paper sheds light on whether Bill 198 has had a significant impact on them.

This study did not find a significant change on the market reaction (abnormal returns) to the announcement of seasoned equity offerings between the pre- and post-Bill time periods, for the overall, the cross-listed and non-cross-listed samples, after conditioning for firm and offer characteristics. A feasible explanation for this finding is that Canadian regulators followed a gradual approach in implementing Bill 198 unlike their U.S. counterparts in implementing SOX. The three-year period from the enactment of Bill 198 to its effective implementation in 2006 may have reduced uncertainty to Canadian issuers and investors. Thus, regulators from countries that expect to pass similar such as SOX and Bill 198 can learn from the Canadian experience. On the other hand, when distinguished by underwritten method, marketed underwritten offers display significant less positive market reaction to SEO announcements than bought deals for the post-Bill period only, mostly for non-cross-listed issuers. A potential explanation for the less positive market reaction for marketed underwritten offers compared to bought deals is found in Pandes (2010). The author argues that marketed underwritten offers are not certified by underwriters unlike bought deals which they are. This may explain why the former have decreased significantly in the last years.

The remainder of the paper is organized as follows. Next section introduces relevant literature review and research hypotheses. Section 3 describes the data and methodology. Section 4presents and analyzes the empirical results. Finally, last section reports the conclusions.

\section{Literature Review and Research Hypotheses}

This section provides a brief comparative review of the Sarbanes-Oxley and Bill 198. It also explains differences between bought deals and marketed 
offers. Next, it presents the theoretical framework including research on the market reaction to seasoned equity offerings with emphasis on Canadian firms, including the effects of SOX. Finally, it presents the research hypotheses.

The Sarbanes-Oxley Act and Canadian Bill 198 are legislations focused in increased transparence in financial reporting of publicly traded firms in the U.S. and Canada, respectively. An important objective of both legislations is to ensure investors make informed financial decisions from accurate and reliable corporate financial information. When publicly traded companies announce equity offerings, they should comply with strict disclosure rules. Announcing a seasoned equity offering is an important firm-event that may have a material impact on the profits of the companies and investors. Therefore, the issuer must provide correct financial information on the equity offer as mentioned in the respective legislation.

Some similarities and differences between SOX and Bill 198 as documented by Emerson and Clarke (2003) and Ben Ashai (2008) are as follows ${ }^{1}$. Both pieces of legislation require $\mathrm{CEO}$ or CFO certification of accuracy of financial statements, including civil liability for secondary market disclosures. Disclosure of control procedures and internal controls over financial reporting to prevent risk of material misstatement is stronger in SOX [section 404] than Bill 198 [NI 52$109]^{2}$. Independency and transparence of public accounting oversight board is also stronger in SOX [section 407]than Bill 198 [NI 52-108]. ${ }^{3}$ Stronger implies heavy fines, and criminal or civil liabilities for companies that fail to comply with regulatory terms. On the other hand, SOX requires an independent audit committee have a financial expert while Bill 198 requires someone who is 'financially literate' [NI 52-110] $]^{4}$. Similarly, SOX requires management reporting of internal controls and external auditor attestation [section 404] while Bill 198 does not [NI 52-109].Sarbanes-Oxley is stricter than Bill 198 because it is a rules-based model of corporate governance while Bill 198 is principles-based model. That is, in the principles-based model capital markets (investors) are the final judges of effective governance practices. In contrast, in the rules-based system companies must comply with SOX governance provisions. The reason Bill 198 did not exactly mirror SOX is to adapt to the needs of the much smaller Canadian publicly traded companies. Thus, reproducing the same rules as SOX would be cumbersome and costly. Also, Canadian regulators considered wise to take the time to amend Bill 198 to be suitable for Canadians. This may avoid mistakes that have occurred on the U.S. in the implementation of SOX (Gray, 2005). Nevertheless, the spirit of Bill 198 is in essence the same as SOX, which is to protect investors from corporate misleading financial information.

Two common underwriting methods of seasoned equity offerings used by companies are bought deals (accelerated offers or shelf-registered offers in the

\footnotetext{
${ }^{1}$ Emerson and Clarke (2003) and Ben Ashai (2008) examine in detail the legal differences between SOX and Bill 198.

${ }^{2}$ NI 52-109 is National Instrument -Certification of Disclosure in Issuers' Annual and Interim Filings.

${ }^{3}$ NI 52-108 is National Instrument - Auditor oversight.

${ }^{4}$ NI 52-110 is National Instrument - Audit committees.
} 
U.S.) and marketed underwritten offers (non-shelf registered offers in the U.S.). In both cases, the underwriter -typically an investment bank- buys the common stock from the issuing company and resells it to investors at a fixed offer price. In both methods, underwriters commit to buy the shares from issuers and assume responsibility for the unsold shares. ${ }^{5}$ Key differences between bought deals and marketed offers as reviewed by Pandes (2010) and Bortolotti et al. (2008) are as follows. Bought deals, unlike marketed underwritten offers, have no market out clause. This means cancellation of the offer cannot occur if the stock price decreases before the issue date- that is, the investment banks assume all price risk. To reduce this risk, the announcement date is the same as the issue date for bought deals, unlike marketed underwritten offers in which the issue date is several days later. For marketed offers the time period between the announcement date and the effective issue date is assigned to book building and road shows. This refers to the procedure followed to estimate the potential demand for the equity offering among institutional investors. It also includes information about the issue to help decide the proper offer size and price. Book building and road shows are absent in bought deals, which reduce marketing and distribution costs. In recent years marketed underwritten offers have declined in favor of bought deals. For example, in 2013 bought deals represent $80 \%$ of all seasoned equity offerings in the U.S., Europe and Canada (Gunay and Ursel 2015).

\section{Theoretical Framework}

The market reaction to seasoned equity offerings is well documented in the financial literature. The market reaction to the announcement of seasoned equity offerings is around -2 percent in the U.S. and the international evidence is mixed (Eckbo et al. 2007) ${ }^{6}$. A negative market reaction to seasoned equity offerings is an important (indirect) cost for issuers. Eckbo and Masulis (1995) show the adverse selection theory examined in Myers and Majluf's (1984) influential paper explains the negative market reaction to the announcement of SEOs. In the adverse selected theory managers will issue shares when the stock is overvalued. Thus, when firms announce an equity offer, investors infer the stock is overvalued and assess its value downwards. For Canadian firms traded in the Toronto Stock Exchange this is around -1.86 percent during the time period 1993-2005 (Pandes 2010). Pandes argues bought deals have more positive market reaction than firm commitment offers (marketed underwritten) because they are certified by underwriters while firm commitment offers are not.

When considering the impact of SOX on seasoned equity offerings, Rubalcava (2012b) finds the market reaction to offer announcements of Canadian firms cross-listed in major U.S. exchanges is -1.25 percent for the pre-SOX period (1995-July 2002) and -3.64 percent for the post-SOX period (August

\footnotetext{
${ }^{5}$ In most (prior) research marketed underwritten offers are called firm commitment offers. However, bought deals and marketed underwritten offers are both on a firm commitment basis. ${ }^{6}$ Eckbo et al. (2007) provide an excellent review of different types of equity offerings including seasoned equity offerings.
} 
2002-2008). The reason the market reaction is more negative for the post-SOX period is for offers issued globally only. ${ }^{7}$ When distinguishing seasoned equity offerings by underwriting method, Rubalcava (2015) finds the market reaction is more negative for firm commitment (marketed underwritten) offers than bought deals for the pre-SOX period only.

Since Canadian Bill 198 is regarded as the 'Sarbanes-Oxley Act of Canada or CSOX', this paper tries to answer the following research questions: Has Canadian Bill 198 had a significant impact on the market reaction to seasoned equity offering for Canadian issuers -cross-listed and non-cross-listed? Has Bill 198 had an effect on the market reaction to seasoned equity offerings on bought deals and marketed underwritten offers, respectively? To answer these questions this paper explores the impact of Bill 198 by comparing the pre-Bill period (January 1999-December 2005) with the post-Bill period (January 2006-December 2011) and verify whether a significant difference between these two time periods exists.

\section{Research Hypotheses}

The null hypotheses to be tested are twofold. The first hypothesis includes four auxiliary hypotheses as follows.

$\mathrm{H} 1^{\text {a }}$ : The market reaction (abnormal returns) to SEO announcements of Canadian firms is the same for the pre- and post-Bill periods for:

(i) all Canadian offers

(ii) cross-listed offers

(iii) non-cross-listed offers

$\mathrm{H} 1^{\mathrm{b}}$ : The market reaction (abnormal returns) to SEO announcements between cross-listed vs. non-cross-listed offers is the same for the:

(i) Pre-Bill period

(ii) Post-Bill period

The second hypothesis includes three auxiliary hypotheses as follows.

$\mathrm{H} 2$ : The market reaction (abnormal returns) to SEO announcements of bought deals vs. marketed underwritten offers of Canadian firms is the same for the pre - and post-Bill periods, respectively, for:

(i) all Canadian offers

(ii) cross-listed offers

(iii) non-cross-listed offers

All hypotheses control for firm and offer characteristics including volume turnover, number of trades, price run-up, offer size, offer purpose and others, which are described later.

\footnotetext{
${ }^{7}$ Global offers include those issued outside Canada or issued concurrently in Canada and other countries; unlike domestic offers, which are issued in Canada only.
} 
The rationale for the first auxiliary hypotheses is as follows. After the SOX, Canadian regulators considered implementing similar law in Canada via a gradual approach to avoid the pitfalls of SOX on capital markets (Gray 2005). Thus, the 3-year period before Bill 198 became effective in December 2005 has allowed Canadian regulators, Canadian cross-listed and non-cross-listed firms, investors and investment banks enough time to adjust to the new legislation. Therefore, no differences on market reaction to offer announcement for the overall, and pre- and post-Bill periods for all firms, including cross-listed and no-cross-listed is expected. Whether similar findings occur for the second auxiliary hypotheses between bought deals versus marketed underwritten offers is explored in the section of empirical results.

\section{Data and Methodology}

\section{Sample and Data}

The sample consists of 550 seasoned equity offerings (common stock) by Canadian firms -cross-listed on the NYSE, AMEX and NASDAQ and those listed on the Toronto Stock Exchange only (non-cross-listed) from 1999 to 2011. The pre-Bill period (January 1999- December 2005) includes 179 SEOs (82 crosslisted, 97 non-cross-listed); the post-Bill period (January 2006 - December 2011) includes 371 SEOs (76 cross-listed and 295 non-cross-listed). Of the 550 SEOs, 449 are bought deals (115 pre-Bill and 334 post-Bill) and 101 are marketed underwritten offers (64 pre-Bill and 37 post-Bill $)^{8}$. Cross- and -non-cross-listed firms are matched using the 4-digit SIC industry code. This allows more reliable comparison results than using non matching samples. Data on seasoned equity offerings including announcement and issue dates, size, proceeds, purpose, type (marketed underwritten offer, bought deal), overallotment option, book runners, cross and non-cross-listed, and domestic and global offers are from FP Advisor and the System for Electronic Documents Analysis and Retrieval (SEDAR). Daily market data including stock prices, volumes, number of trades, S\&P/TSX value weighted index and monthly number of shares outstanding are from the Canadian Financial Markets Research Centre (CFMRC).The Canadian monthly T-bill rate (proxy for the risk-free rate) is from Statistics Canada (CANSIM). The data include companies with shares prices over $\$ 2$ dollars. Equity offerings with missing data or errors are not included. ${ }^{9}$

\footnotetext{
${ }^{8}$ The rationale for including only marketed underwritten offers and bought deals is they face more adverse information asymmetry than other underwriting methods such as 'best efforts'. The former should result in stronger market reaction to offer announcements than the latter (Eckbo et al., 2007).

9 The original data includes 991 SEOs. Of these 491 were dropped -138 had incomplete, missing data or errors, and 98 had prices less than $\$ 2$ and 205 had no matching sample.
} 


\section{Abnormal Returns Model}

This section presents the model of abnormal returns (market reaction) around the announcement of seasoned equity offerings. A modified version of the asset pricing model of Foerster and Karolyi (1999) is used to calculate the abnormal returns around the announcement of seasoned equity offerings as follows.

$$
\begin{aligned}
& R_{i t}=a_{i}+b_{i} R_{M}^{T S X}+c_{i} R_{M}^{T S X} * \text { Dum } 1+\gamma_{1 i} \text { DumCARPreAD } D_{t}+\gamma_{2 i} \text { DumAD }_{t}+\gamma_{3 i} \\
& \text { DumCARPostAD } D_{t}+\varepsilon_{i t}
\end{aligned}
$$

Where $R_{i t}$ is the continuously compounded daily excess return for the trades executed on the TSX for cross-listed issuer $i$, and is equal to the stock return for the closing trade executed on the TSX for issuer $i$ minus the Canadian T-bill rate (risk-free). Thus, $R_{M}^{T S X}$ is equal to the return of the S\&P/TSX composite valueweighted index minus the monthly Canadian risk-free rate. The dummy variable Duml is included to account for the possibility that the market beta could change by the offer announcement. It is equal to one for each day in the period from two to 26 days after the announcement day (AD). The dummy variable DumCARPreAD, which occurs in the pre-announcement window, is equal to one for days -26 through -2 before the announcement day of the equity offer, i.e., [AD-26, AD-2], and is zero otherwise. This dummy variable is included to control for any positive abnormal performance before the announcement date. $\operatorname{DumAD}_{t}$ measures the market reaction or abnormal returns at the firm's offer announcement date. This is a dummy variable that equals one on the three-day announcement date [AD-1, AD+1], and is zero otherwise. The three-day period is suitable for capturing the market's response on the announcement date of the SEOs. The $3 \gamma_{2 i}$ is three day cumulative abnormal return or CAR for firm $i$ for the offer announcement date, [AD-1, AD+1], and is used for marketed underwritten offers only. An adjusted $C A R\left(C A R_{a d j}\right)$ for bought deals is used as in Pandes (2010). The formula is $C A R_{a d j}=(1 /(1-\alpha)) C A R+(\alpha /(1-\alpha))\left[P_{b}-P_{o} / P_{b}\right]$, where $\alpha$ is the number of shares issued divided by the number of shares outstanding after the issue; $P_{b}$ is the shares price prior the offer announcement; and $P_{o}$ is the offering price. This formula removes the price discount effect on $C A R$ for bought deals, which is estimated at the SEO announcement unlike marketed underwritten offer in which is estimated before the closing date of the issue. The price discount occurs when the offer price is lower than the closing price on the day before the issue date.

The dummy variable DumCARPostAD $D_{t}$ is equal to one for the period from 2 through 26 days after the announcement day, [AD+2, AD+26], and is zero otherwise. The abnormal returns for the announcement date and the other windows for the sample of SEOs are estimated simultaneously using the 200 trading days prior to the announcement day and ending 75 trading days after the announcement day. This time period allow us to getting reliable parameter 
estimates. ${ }^{10}$ Equity offers with fewer than 200 trading days are omitted. The CARs for each event window are averaged across all equity issues. The cumulative average abnormal return (CAARs) are tested for significance using a Z-statistic assuming stock returns are log-normally distributed and cross-section independent. ${ }^{11}$ CAAR or parameter estimates that are statistically significant at the $0.01,0.05$ or 0.10 levels are referred here as highly significant, significant or marginally significant, respectively.

\section{Hypotheses Testing Model}

The cross-sectional model used for testing hypotheses 1 and 2 is the following.

CAR $_{i}=a_{0}+\left(a_{1}+\delta_{\text {DumCross }}\right.$ DumPerBill $)$ DumCross ${ }_{i}+\left(a_{2}+\delta_{\text {DumMUOD DumPer }}\right.$ Bill) DumMUO ${ }_{i}+\left(a_{3}+\delta_{R U N U P}\right.$ DumPerBill $) R U N U P_{i}+\left(a_{4}+\delta_{R E L O F F E R}\right.$ DumPer Bill)RELOFFER $R_{i}+\ldots+a_{n}$ DumYEAR $_{t=2000}+\ldots+a_{n+12}$ DumYEAR $_{t=2011}+\varepsilon_{i}(2)$

This model examines the relation of $C A R$ and the expected determinants simultaneously for the pre- and post-Bill periods. It is used for testing the determinants of $C A R$ - including marketed underwritten offers and bought deals- for the overall, cross-listed and non-cross-listed samples of seasoned equity offerings, respectively. The testing of hypotheses 1 and 2 is performed in last section.

The description of variables in equation (2) is as follows. $C A R_{i}$ is the abnormal return for the SEO announcement window [AD-1, AD+1] and is equal to $3 \gamma_{2}$ from equation (1) for marketed underwritten offers. $C A R_{a d j}$ is the adjusted abnormal return for bought deals, as in Pandes (2010). The subscript $I$ stands for issuer $i$.

The determinants included in equation (2) are from the literature of SEOs and economic intuition. They account for information asymmetry, information related volatility, price pressure, price run-up, and underwriter reputation. It also includes indicator variables that control for underwriting method (marketed underwritten offers, bough deals), purpose of the offer, location of the SEO (domestic, global), cross-listing exchange venue (Canada, U.S.) whether the SEO has an overallotment option, and dummy years for market conditions. The expected or undetermined (U) sign of the coefficient estimates is indicated in brackets (whenever necessary). The relevant determinants and identifiers are as follows.

DumPerBill[U]. Dummy variable which equals one during the time period before Bill 198 (DumPreBill) and zero otherwise (DumPostBill).

DumCross[U]. Dummy variable which equals one if the issuer is crosslisted in NYSE, AMEX or NASDAQ and zero if it is listed on the TSX only.

\footnotetext{
${ }^{10}$ A minimum event window of 100 days before the announcement day for the calculation of CAR for SEOs has been documented by Foerster and Karolyi (1999) and a minimum of 250 days by Pandes (2010).

${ }^{11}$ Unreported results show this is the case.
} 
DumMUO [U]. Dummy variable which equals one if it is a marketed underwritten offer and zero if it is a bought deal $(B D)$.

RUNUP [U]. Abnormal return for the SEO pre-announcement window [AD-26, AD-2] and is equal to $25 \gamma_{1}$ from equation (1) or DumCARPreAD. It proxies for the price run up as in Pandes (2010).

$T O[+]$. Volume turnover and is equal to the average of the daily annualized share volume divided by the number of shares outstanding. It measures noninformed trading (Easley et al. 1996).

RELOFFER [-]. Ratio of the offer size to the total number of shares outstanding pre-announcement. It measures price pressure. (Loderer et al. 1991).

CHTRADES[-]. Change in the average number of trades between the period [AD-120, AD-61] and [AD-60, AD-2], where AD is the announcement date of the equity offer. It is a proxy for information-related volatility (Jiang and Kryzanowski 1998).

BRUNNERS [+]. Ratio of the number of times an investment bank appears as a book runner in a SEO in a given year divided by the average number of all book runners in the previous year. It measures underwriter reputation. The positive relation between $C A R$ and underwriter reputation is based on the argument by Jeon and Ligon (2011) who argue that issuers will hire top underwriters because of their higher efficiency and lower underwriting costs.

DumGLO [-]. Dummy variable that equals one if the SEO is issued concurrently in the U.S. and Canada and zero if it is issued in Canada only. The predicted negative sign is from the empirical results of Rubalcava (2012b) who finds the market reaction to SEOs of Canadian cross-listed firms floated in the U.S. is less positive than those in Canada during the post-SOX period (20032008).

DumOAO [+]. Dummy variable that equals one if the SEO has an overallotment option and is zero otherwise. Including an overallotment option on the equity offer is a positive signal to investors that the offer is not overpriced (Ritter, 1998).

Dum0 to Dum4 are dummy variables that classify the purpose of the SEO as follows: Dum0 (unknown), Duml (working capital), Dum2 (capital investment), Dum3 (general corporate) and Dum4 (debt reduction). The five categories are from the FP Advisor database. The expected sign for each purpose is unknown. However, a valid prediction is that, by using as a reference the dummy Dum0 (unknown), the coefficient estimates of the other dummies should be positive and significant compared to the coefficient estimate of Dum0. The reason isDumOrevealsno specific offer purpose -an undesired feature by investors- than the other dummies.

$\operatorname{DumYEAR}_{\tau}$ are dummy variables included to control for annual economic conditions during the overall sample period from 1999 to 2011.

$\varepsilon_{i}$ is the error term that is assumed to be independently and normally distributed ; i.e., $\varepsilon_{i} \sim N\left(0, \sigma^{2}\right)$. 


\section{Data Analysis -Descriptive Statistics}

Table 1 presents annual statistics on the number of seasoned equity offerings and gross proceeds of Canadian firms from 1999 to 2011 for the matched sample of 550 SEOs. Panel A of Table 1 reports the number of SEOs and gross proceeds by year in columns (1) to (3), including the pre-Bill and post-Bill periods (last two rows). Columns (4) to (11) report the number of SEOs and mean gross proceeds each year for non-cross-listed, cross-listed, bought deals and marketed underwritten offers, respectively. The number of SEOs jumps significantly in 2006 and 2007, mostly for non-cross-listed firms and bought deals. In 2008 (the year of the financial meltdown) the SEO figures decrease drastically and recover the following year. Interestingly, the recovery is mainly for bought deals of non-cross-listed issues. For example, of the 73 bought deals in 2009, 53 are for non-cross-listed issues and 20 for cross-listed issues (not-reported); only 2 issues are marketed underwritten offers for non-cross-listed firms and zero issues for cross-listed firms (not reported). Similar pattern as 2009 occurs in 2011. For gross proceeds, the mean issue size increases significantly during the post-Bill period compared with the pre-Bill period, for non-cross-listed, crosslisted and bought deals, respectively. However, the mean offer size for marketed underwritten offers decreases significantly after the passage of Bill 198. Panel B confirms above results. For example, the ratio of number of bought deals (marketed underwritten offers) to total SEOs during the pre-Bill period is 64.2 percent (35.8 percent). However, during the post-Bill period, the ratio of bought deals (marketed underwritten offers) increases (decreases) significantly to 90.0 percent (10.0 percent). These results confirm the findings of Gunay and Ursel (2015) that marketed underwritten offers have declined significantly in favor of bought deals. 
Table 1. Descriptive Statistics of Canadian SEOS

\begin{tabular}{|c|c|c|c|c|c|c|c|c|c|c|}
\hline \multicolumn{11}{|l|}{ Panel A } \\
\hline \multicolumn{3}{|c|}{ All SEOs } & \multicolumn{2}{|c|}{ Non-Cross-Listed } & \multicolumn{2}{|c|}{ Cross-Listed } & \multicolumn{2}{|c|}{ Bought Deals } & \multicolumn{2}{|c|}{ Marketed Underwritten } \\
\hline (1) & (2) & (3) & (4) & (5) & (6) & (7) & (8) & (9) & (10) & (11) \\
\hline Year & Number & Gross Proceeds & Number & Mean issue size & Number & Mean issue size & Number & Mean issue size & Number & Mean issue size \\
\hline 1999 & 13 & $2,443,150,950$ & 0 & 0 & 13 & $187,934,688$ & 5 & $122,475,000$ & 8 & $228,846,994$ \\
\hline 2000 & 16 & $908,584,883$ & 8 & $52,300,110$ & 8 & $61,273,000$ & 10 & $61,860,838$ & 6 & $48,329,417$ \\
\hline 2001 & 26 & $2,306,785,042$ & 13 & $67,487,746$ & 13 & $109,957,257$ & 14 & $95,952,254$ & 12 & $79,121,124$ \\
\hline 2002 & 29 & $3,097,703,094$ & 18 & $61,836,540$ & 11 & $180,422,307$ & 19 & $104,573,291$ & 10 & $111,081,057$ \\
\hline 2003 & 28 & $2,380,452,262$ & 14 & $75,017,004$ & 14 & $95,015,300$ & 17 & $76,424,232$ & 11 & $98,294,574$ \\
\hline 2004 & 33 & $7,009,732,901$ & 19 & $69,147,564$ & 14 & $406,852,085$ & 25 & $74,186,969$ & 8 & $644,382,335$ \\
\hline 2005 & 34 & $2,392,598,047$ & 25 & $61,121,262$ & 9 & $96,062,944$ & 25 & $73,208,972$ & 9 & $62,485,973$ \\
\hline 2006 & 53 & $3,478,277,650$ & 40 & $55,944,208$ & 13 & $95,423,796$ & 42 & $45,152,555$ & 11 & $138,109,185$ \\
\hline 2007 & 86 & $11,945,468,748$ & 69 & $103,098,176$ & 17 & $257,746,743$ & 70 & $122,293,692$ & 16 & $183,431,896$ \\
\hline 2008 & 32 & $11,405,424,860$ & 24 & $153,431,161$ & 8 & $965,383,125$ & 29 & $385,178,357$ & 3 & $78,417,500$ \\
\hline 2009 & 75 & $9,944,619,435$ & 55 & $107,147,805$ & 20 & $202,574,509$ & 73 & $131,614,513$ & 2 & $168,380,000$ \\
\hline 2010 & 55 & $5,114,363,138$ & 44 & $97,838,844$ & 11 & $73,586,727$ & 51 & $94,641,924$ & 4 & $71,906,250$ \\
\hline 2011 & 70 & $9,479,216,301$ & 63 & $122,100,248$ & 7 & $255,271,522$ & 69 & $137,133,570$ & 1 & $17,000,000$ \\
\hline $1999-2011$ & 550 & $71,906,377,311$ & 392 & $78,959,282$ & 158 & $229,808,000$ & 449 & $117,284,321$ & 101 & $148,445,100$ \\
\hline Pre-Bill & 179 & $20,539,007,179$ & 97 & $55,272,889$ & 82 & $162,502,512$ & 115 & $86,954,508$ & 64 & $181,791,639$ \\
\hline Post-Bill & 371 & $51,367,370,132$ & 295 & $106,593,407$ & 76 & $308,331,070$ & 334 & $152,669,102$ & 37 & $109,540,805$ \\
\hline
\end{tabular}

\begin{tabular}{lcll}
\multicolumn{1}{c}{ Panel B } & & & \\
\hline BD/all SEOs & $81.6 \%$ & MUO/all SEOs $18.4 \%$ & $18.4 \%$ \\
\hline BD/SEOs Pre-Bill & $64.2 \%$ & MUO/SEOs Pre-Bill & $35.8 \%$ \\
\hline BD/SEOS Post-Bill & $90.0 \%$ & MUO/SEOs Post-Bill & $10.0 \%$ \\
\hline Source: Source: Own Calculation on the basis of FP advisor and SEDAR data
\end{tabular}




\section{Data Analysis - Descriptive Statistics}

Table 2 reports the mean (median) CAAR around the announcement date of seasoned equity offerings of all Canadian issuers, including cross-listed and non-cross-listed for the pre-Bill period (column 1) and the post-Bill 198 period (column 2). P-values for the difference of the mean (median) values are reported in column (3). The number of equity offers is in brackets. Interestingly, the p-values of the difference on the mean (median) CAAR between the preand post-Bill periods are not significant for the overall, and cross-listed and non-cross-listed SEOs, respectively. On the other hand, the p-values for the difference of the mean (median) values between cross-listed and non-crosslisted SEOs are reported in the last row. It shows the p-values of the difference on the mean CAAR between cross-listed and non-cross-listed are not significant for the pre- and post-Bill periods, respectively. (The p-value of the difference on the median CAAR is significant for the post-Bill period at the 10 percent level only). These preliminary results suggest the passage of Bill 198 has not had a significant impact on the market reaction to offer announcements for the overall, cross-listed and non-cross-listed samples, respectively.

Table 2. CAAR for SEOs of Canadian Firms for the Overall, Pre-and Post-Bill Time Periods

\begin{tabular}{cccc}
\hline & $\begin{array}{c}(1) \\
\text { Pre-Bill } \\
\text { Period }\end{array}$ & Post-Bill Period & $\begin{array}{c}(3) \\
\text { P-value diff. } \\
\text { Mean } \\
\text { (Median) }\end{array}$ \\
\hline All SEOs & {$[179]$} & {$[371]$} & 0.7537 \\
& $-1.88 \%$ & $-2.09 \%$ & $(0.5321)$ \\
& $(-2.51 \%)$ & $(-2.60 \%)$ & \\
Cross-listed & {$[82]$} & {$[76]$} & 0.4068 \\
& $-2.15 \%$ & $-3.25 \%$ & $(0.2973)$ \\
Non-cross-listed & $(-2.72 \%)$ & $(-3.71 \%)$ & \\
& {$[97]$} & {$[295]$} & 0.8608 \\
P-value & $-1.64 \%$ & $-1.79 \%$ & $(0.6156)$ \\
Mean & $(-2.47 \%)$ & $(-2.41 \%)$ & \\
(Median) & 0.6935 & 0.1382 & \\
\hline
\end{tabular}

* denotes significance at the 10 percent level using t-test for the mean and Wilcoxon/MannWhitney for the median.

Source: Own Calculation on the basis of FP advisor, SEDAR, and CFMRC data.

Table 3 reports the mean (median) CAAR around the announcement date of seasoned equity offerings of Canadian issuers for the pre- and post-Bill time periods distinguished by the method of underwriting, i.e., bought deal versus marketed underwritten offer. Panel A includes all 550 SEOs, and Panels B and C include only cross-listed and non-cross-listed SEOs, respectively. Column (3) of Panel A shows the p-value of the difference on mean (median) CAAR between bought deals and marketed underwritten offers is statistically significant for the pre-Bill period. Column (6) report similar significant results occur for the post- 
Bill period. In both Bill periods, the mean (median) CAAR values are significantly more negative for marketed underwritten offers than bought deals. On the other hand, Panel B shows the p-value of the difference on mean (median) CAAR values between bought deals and marketed underwritten offers is not significantly different for the pre-Bill (column 3) and post-Bill (column 6) periods, respectively. However, Panel $\mathrm{C}$ shows that for non-cross-listed SEOs, the mean CAAR values of the marketed underwritten offers are more negative than those of bought deals during the pre-Bill (significantly) and post-Bill (marginally significant) periods, respectively. These preliminary results suggest the market reaction to the announcement of marketed underwritten offers is less favorable than for bought deals for both Bill periods, for the non-cross-listed issuers only. Whether these results hold after controlling for offer and firm characteristics is explored in the empirical results section.

Table 3. CAAR for SEOs of Canadian Issuers for the Pre and Post-Bill Time Periods distinguished by Underwriting Method: Bought Deal (BD) vs. Marketed Underwritten Offer (MUO

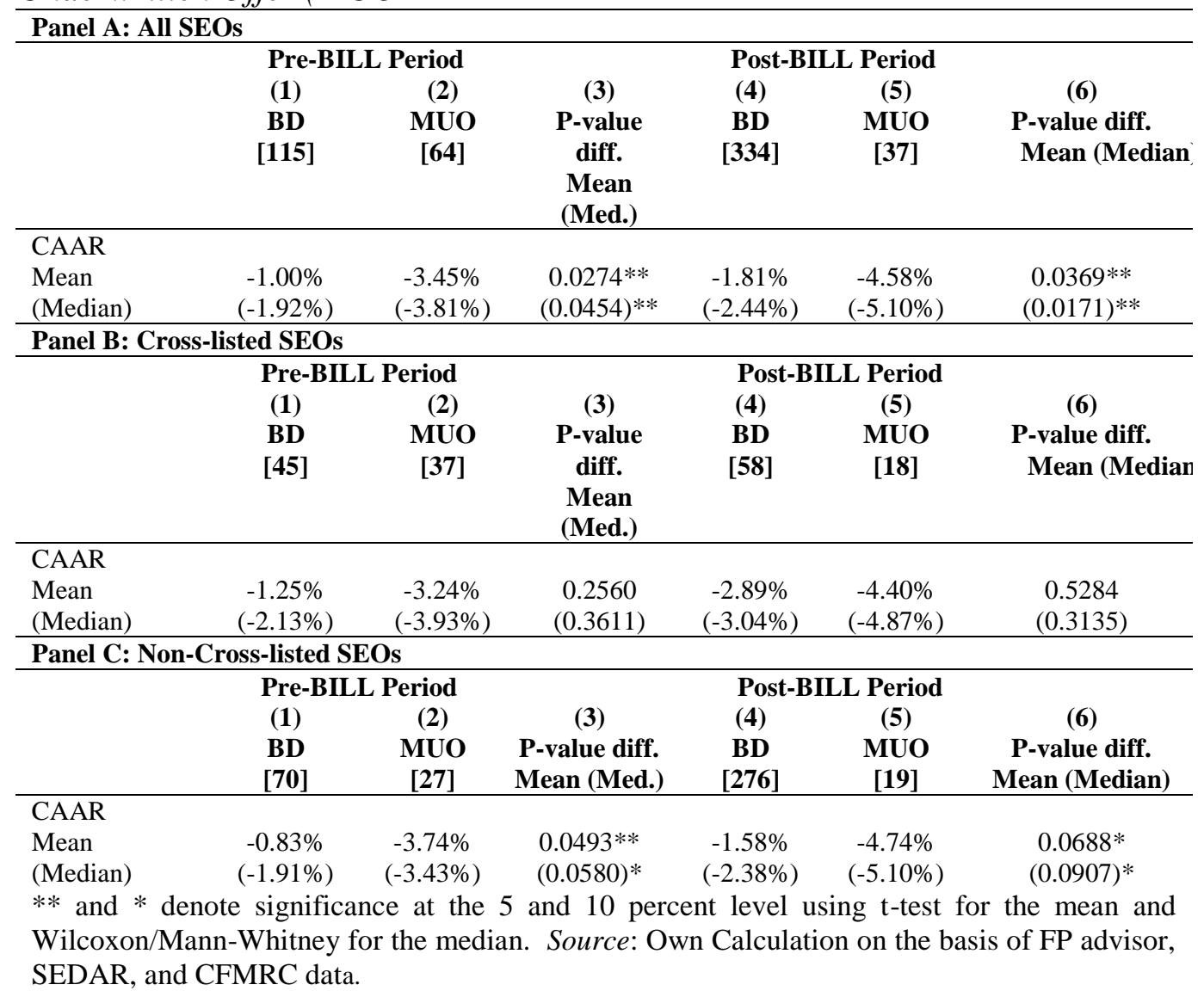

Descriptive Statistics for Determinants of Abnormal Returns

Table 4 presents descriptive statistics for the determinants of the market reaction to SEOs of Canadian issuers for the overall, pre- and post-Bill periods based on equation (2). Panel A.1 displays the mean (median) values of the 
determinants for the full-time period (column 1) for all SEOs. Also, it displays the values for the pre- and post-Bill periods for all SEOs (column 2 and 3), for the cross-listed SEOs (columns 5 and 6), and for the non-cross-listed SEOs (columns 8 and 9), respectively. P-values for the difference of means (median) values are also reported between the pre- and post-Bill periods for all SEOs (column 4), between the pre- and post-Bill periods for the cross-listed firms (column 7), and between the pre- and post-Bill periods for the non-cross-listed firms (column 10). This panel shows that none of the expected determinants except share turnover (TO) report significant differences in mean (median) values for the overall and non-cross-listed SEO samples. Specifically, the p-value of the difference of the mean value of share turnover (TO) is 0.0598 (marginally significant at the 0.10 level) for the overall sample and 0.0409 (significant at the 0.05 level) for the non-cross-listed sample. In both samples TO is higher for the post-Bill period than the pre-Bill period. This result suggests noninformed trading increased after the passage of Bill 198. (The p-value for the difference of mean values of CHTRADES between the pre- and post-Bill periods is not significant because the standard deviation across all issues is very high during the post-Bill period.)

Panel A.2 reports the number of SEOs for the indicator variables used in equation (2). They account for domestic and global SEOs, with overallotment option, and SEO purpose during the full, pre- and post-Bill periods for the overall SEOs (columns 1, 2 and 3), cross-listed SEOs (columns 5 and 6) and non-cross-listed SEOs (columns 8 and 9). Global offers are about 11 and 13 percent of total SEOs for the pre- and post-Bill periods, respectively. Interestingly, the number of global SEOs floated during the post-Bill period increased significantly for Canadian cross-listed issuers from 20 to 48 (of which 85 percent and 29 percent were marketed underwritten offers, respectively; unreported). On the other hand, the number of domestic SEOs floated during the post-Bill period decreased significantly for Canadian cross-listed issuers from 62 to 28 offers (of which 32 percent and 14 percent were marketed underwritten offers, respectively; unreported). For Canadian non-cross-listed issuers, the number of SEOs floated for the post-Bill period jumped significantly from 97 to 295 domestic offers (of which 29 percent and 6 percent are underwritten offers, respectively; unreported). The results show marketed underwritten offers declined significantly in favor of bought deals after the passage of Bill 198, for cross-listed and non-cross-listed issuers.

On the other hand, the number of SEOs with an overallotment option increased significantly from the pre- to the post-Bill period, mostly for noncross-listed issuers (from 22 to 166). For SEO purpose, capital investment (D2) showed a significant increase from the pre- to post-Bill period, mostly for noncross-listed issuers (from 37 to 193). The section of empirical results explores whether offers with an overallotment option or capital investment purpose show a favorable market reaction. 
Table 4. Determinants of SEOs of Canadian Firms for the Overall, Pre-and Post-Bill Time Periods

Panel A.1

\begin{tabular}{|c|c|c|c|c|c|c|c|c|c|c|}
\hline & (1) & (2) & (3) & (4) & (5) & (6) & (7) & (8) & (9) & (10) \\
\hline & \multicolumn{5}{|c|}{ Overall SEOs } & Cross-listed SEOs & \multicolumn{4}{|c|}{ Non-Cross-listed SEOs } \\
\hline & $\begin{array}{c}\text { Full Period } \\
{[550]}\end{array}$ & $\begin{array}{c}\text { Pre-Bill } \\
{[179]} \\
\end{array}$ & $\begin{array}{c}\text { Post-Bill } \\
{[371]}\end{array}$ & $\begin{array}{c}\text { P-value } \\
\text { diff. }\end{array}$ & $\begin{array}{c}\text { Pre-Bill } \\
{[82]} \\
\end{array}$ & $\begin{array}{c}\text { Post-Bill } \\
{[76]}\end{array}$ & $\begin{array}{c}\text { P-value } \\
\text { diff. }\end{array}$ & $\begin{array}{c}\text { Pre-Bill } \\
{[97]}\end{array}$ & $\begin{array}{c}\text { Post-Bill } \\
{[295]}\end{array}$ & $\begin{array}{c}\text { P-value } \\
\text { diff. }\end{array}$ \\
\hline RUNUP & $\begin{array}{c}0.0695 \\
(0.0551) \\
\end{array}$ & $\begin{array}{c}0.0756 \\
(0.0735) \\
\end{array}$ & $\begin{array}{l}0.0666 \\
(0.047) \\
\end{array}$ & $\begin{array}{c}0.5807 \\
(0.1908) \\
\end{array}$ & $\begin{array}{c}0.0651 \\
(0.0685) \\
\end{array}$ & $\begin{array}{c}0.0663 \\
(0.0624) \\
\end{array}$ & $\begin{array}{c}0.9670 \\
(0.7383) \\
\end{array}$ & $\begin{array}{c}0.0845 \\
(0.0735) \\
\end{array}$ & $\begin{array}{c}0.0667 \\
(0.0451) \\
\end{array}$ & $\begin{array}{c}0.3870 \\
(0.1999) \\
\end{array}$ \\
\hline TO & $\begin{array}{c}110.64 \\
(84.31)\end{array}$ & $\begin{array}{c}97.52 \\
(78.57) \\
\end{array}$ & $\begin{array}{l}116.97 \\
(87.79)\end{array}$ & $\begin{array}{c}0.0598 * \\
(0.0387)^{* *}\end{array}$ & $\begin{array}{l}101.05 \\
(86.78) \\
\end{array}$ & $\begin{array}{c}85.94 \\
(74.84) \\
\end{array}$ & $\begin{array}{c}0.1510 \\
(0.1023)\end{array}$ & $\begin{array}{c}94.53 \\
(65.91) \\
\end{array}$ & $\begin{array}{l}124.96 \\
(89.22) \\
\end{array}$ & $\begin{array}{c}0.0409 * * \\
(0.0004) * * *\end{array}$ \\
\hline RELOFFER & $\begin{array}{c}0.1628 \\
(0.1076)\end{array}$ & $\begin{array}{c}0.1330 \\
(0.1097) \\
\end{array}$ & $\begin{array}{c}0.1172 \\
(0.1057) \\
\end{array}$ & $\begin{array}{c}0.1588 \\
(0.7493) \\
\end{array}$ & $\begin{array}{c}0.1214 \\
(0.1025) \\
\end{array}$ & $\begin{array}{c}0.1375 \\
(0.1014) \\
\end{array}$ & $\begin{array}{c}0.3325 \\
(0.8170) \\
\end{array}$ & $\begin{array}{c}0.1428 \\
(0.1171) \\
\end{array}$ & $\begin{array}{c}0.1875 \\
(0.1067) \\
\end{array}$ & $\begin{array}{c}0.3428 \\
(0.8655) \\
\end{array}$ \\
\hline CHTRADES & $\begin{array}{c}3,219.78 \\
(25.65) \\
\end{array}$ & $\begin{array}{c}36.65 \\
(14.62) \\
\end{array}$ & $\begin{array}{c}4,750.83 \\
(38.99) \\
\end{array}$ & $\begin{array}{c}0.4688^{(a)} \\
(0.0150)^{* *}\end{array}$ & $\begin{array}{c}48.69 \\
(29.20) \\
\end{array}$ & $\begin{array}{c}22,433 \\
(111.08) \\
\end{array}$ & $\begin{array}{c}0.2938 \\
(0.0130)^{* *}\end{array}$ & $\begin{array}{c}26.60 \\
(11.95)\end{array}$ & $\begin{array}{l}179.77 \\
(31.60)\end{array}$ & $\begin{array}{c}0.2737 \\
(0.0332)^{* *}\end{array}$ \\
\hline BRUNNERS & $\begin{array}{c}1.1784 \\
(0.9737) \\
\end{array}$ & $\begin{array}{c}1.2069) \\
(0.8065)\end{array}$ & $\begin{array}{c}1.1646 \\
(0.9736)\end{array}$ & $\begin{array}{c}0.6343 \\
(0.6776) \\
\end{array}$ & $\begin{array}{c}1.075 \\
(0.7862) \\
\end{array}$ & $\begin{array}{c}1.1313 \\
(1.1157)\end{array}$ & $\begin{array}{c}0.6978 \\
(0.7794) \\
\end{array}$ & $\begin{array}{c}1.3181 \\
(0.9915)\end{array}$ & $\begin{array}{c}1.1732 \\
(0.9736)\end{array}$ & $\begin{array}{c}0.2183 \\
(0.8202)\end{array}$ \\
\hline
\end{tabular}

\begin{tabular}{|c|c|c|c|c|c|c|c|c|}
\hline & \multirow{2}{*}{ (1) } & (2) & (3) & (5) & (6) & \multirow{3}{*}{ (7) } & (8) & (9) \\
\hline & & \multicolumn{2}{|c|}{ Overall SEOs } & \multicolumn{2}{|c|}{ Cross-listed SEOs } & & \multicolumn{2}{|c|}{$\begin{array}{c}\text { Non-Cross-listed } \\
\text { SEOs }\end{array}$} \\
\hline & $\begin{array}{c}\text { Full Period } \\
{[550]}\end{array}$ & $\begin{array}{c}\text { Pre-Bill } \\
\text { [179] }\end{array}$ & $\begin{array}{c}\text { Post-Bill } \\
\text { [371] }\end{array}$ & $\begin{array}{c}\text { Pre-Bill } \\
{[82]}\end{array}$ & $\begin{array}{c}\text { Post-Bill } \\
{[76]}\end{array}$ & & $\begin{array}{c}\text { Pre-Bill } \\
\text { [97] }\end{array}$ & $\begin{array}{c}\text { Post-Bill } \\
\text { [295] }\end{array}$ \\
\hline $\begin{array}{l}\text { Domestic } \\
\text { SEOs }\end{array}$ & 482 & 159 & 323 & 62 & 28 & & 97 & 295 \\
\hline Global SEOs & 68 & 20 & 48 & 20 & 48 & & - & - \\
\hline $\begin{array}{l}\text { Overallotment } \\
\text { Options }\end{array}$ & 266 & 51 & 215 & 29 & 49 & & 22 & 166 \\
\hline D0 & 30 & 15 & 15 & 11 & 4 & & 4 & 11 \\
\hline D1 & 72 & 42 & 30 & 18 & 9 & & 24 & 21 \\
\hline D2 & 301 & 62 & 239 & 25 & 46 & & 37 & 193 \\
\hline D3 & 66 & 29 & 37 & 16 & 10 & & 13 & 27 \\
\hline D4 & 81 & 31 & 50 & 12 & 7 & & 19 & 43 \\
\hline
\end{tabular}




\begin{tabular}{|c|c|c|c|c|c|c|}
\hline Panel B & \multicolumn{3}{|c|}{ Pre-BILL Period } & \multicolumn{3}{|c|}{ Post-BILL Period } \\
\hline & (1) & $(2)$ & (3) & (4) & (5) & (6) \\
\hline & $\begin{array}{c}\text { Cross-Listed } \\
{[82]} \\
\end{array}$ & $\begin{array}{c}\text { Non-Cross-Listed } \\
{[97]}\end{array}$ & $\begin{array}{c}\text { P-value diff. } \\
\text { Mean } \\
\text { (Median) } \\
\end{array}$ & $\begin{array}{c}\text { Cross-Listed } \\
{[76]} \\
\end{array}$ & $\begin{array}{c}\text { Non-Cross-Listed } \\
{[295]}\end{array}$ & $\begin{array}{c}\text { P-value diff. } \\
\text { Mean } \\
\text { (Median) } \\
\end{array}$ \\
\hline RUNUP & $\begin{array}{c}0.0651 \\
(0.0685)\end{array}$ & $\begin{array}{c}0.0845 \\
(0.0735)\end{array}$ & $\begin{array}{c}0.5195 \\
(0.9827)\end{array}$ & $\begin{array}{c}0.0663 \\
(0.0624)\end{array}$ & $\begin{array}{c}0.0667 \\
(0.0451)\end{array}$ & $\begin{array}{c}0.9855 \\
(0.4855)\end{array}$ \\
\hline TO & $\begin{array}{l}101.05 \\
(86.78)\end{array}$ & $\begin{array}{c}94.53 \\
(65.91)\end{array}$ & $\begin{array}{c}0.6564 \\
(0.0318)\end{array}$ & $\begin{array}{c}85.94 \\
(74.84)\end{array}$ & $\begin{array}{l}124.96 \\
(89.22)\end{array}$ & $\begin{array}{c}0.0115 * * \\
(0.0059) * * *\end{array}$ \\
\hline RELOFFER & $\begin{array}{c}0.1214 \\
(0.1025)\end{array}$ & $\begin{array}{c}0.1428 \\
(0.1171)\end{array}$ & $\begin{array}{c}0.1623 \\
(0.2821)\end{array}$ & $\begin{array}{c}0.1375 \\
(0.1014)\end{array}$ & $\begin{array}{c}0.1875 \\
(0.1067)\end{array}$ & $\begin{array}{c}0.3475 \\
(0.5183)\end{array}$ \\
\hline CHTRADES & $\begin{array}{c}48.69 \\
(29.20)\end{array}$ & $\begin{array}{c}26.60 \\
(11.95)\end{array}$ & $\begin{array}{c}0.1484 \\
(0.0812)^{*}\end{array}$ & $\begin{array}{c}22,433 \\
(111.08)\end{array}$ & $\begin{array}{l}179.77 \\
(31.60)\end{array}$ & $\begin{array}{c}0.0460 * * \\
(0.0098)^{* * *}\end{array}$ \\
\hline BRUNNERS & $\begin{array}{c}1.075 \\
(0.7862)\end{array}$ & $\begin{array}{l}1.3181 \\
(0.9915)\end{array}$ & $\begin{array}{c}0.1397 \\
(0.5763)\end{array}$ & $\begin{array}{l}1.1313 \\
(1.1157)\end{array}$ & $\begin{array}{c}1.1732 \\
(0.9736)\end{array}$ & $\begin{array}{c}0.7221 \\
(0.6755)\end{array}$ \\
\hline
\end{tabular}


Panel B of Table 4 reports the mean (median) values of the SEO determinants for cross-listed and non-cross-listed firms for the pre-Bill period (columns 1 and 2) and for the post-Bill period (columns 4 and 5), respectively. The mean (median) value of volume turnover (TO) (proxy for non-informed trading) is significantly higher for non-cross-listed SEOs than cross-listed SEOs ( $p$-value difference of 0.0115 ) for the post-Bill period only. Similar result occurs for change in trades (CHTRADES) -proxy for firm specific volatility- (p-value difference of 0.0460). No other determinants show significant change in mean (median) value between cross-listed versus non-cross-listed for the pre- and post-Bill periods, respectively. The impact of the determinants on the market reaction to equity offers is examined in the next section.

\section{Empirical Results}

\section{Testing of H1 Auxiliary Hypotheses}

This section tests the four H1auxiliary hypotheses using the cross-sectional regression model (2). Columns (1) to (3) of the table 5report regressions of CAAR on the independent variables for all SEOs, and for the entire, pre- and post-Bill periods, respectively. Regression (1) (used in testing $\mathrm{H} 1^{\mathrm{a}}(\mathrm{i})$ ), reports the coefficient estimates of the determinants for the overall sample and for the entire time period. The coefficient estimate of the dummy variable DumPerBill, which is post-Bill in regression (1), is not significant after controlling for offer and firm characteristics $(-0.0245$, p-value of 0.1630$)$. This result shows the market reaction to offer announcements is not significantly different between the preand post-Bill periods for all Canadian offers. Thus, hypothesis $\mathrm{H} 1^{\mathrm{a}}(\mathrm{i})$ is not rejected, which is consistent with the preliminary results reported in Table 2.

On the other hand, most control variables display expected signed coefficient except BRUNNERS (-0.0069, p-value of 0.0372), which suggests investors react unfavorable to offerings by investment banks with high relative number of underwritings. The coefficient estimates of marketed underwritten offers (DumMUO) and global SEOs (DumGLO) are negative and significant. This reveals investors react negatively (positively) to marketed offers (bought deals) and global (domestic) issues, respectively.

Similarly, regression (4) (used in testing $\mathrm{H}^{\mathrm{a}}$ (ii)), reports the coefficient estimates of the determinants for the cross-listed sample and for the entire time period. The coefficient estimate of the dummy variable DumPerBill, which is post-Bill in regression (4), is not significant (-0.0009, p-value of 0.9786$)$. This result shows the market reaction to offer announcements is not significantly different between the pre- and post-Bill periods for the cross-listed Canadian offers. Thus, hypothesis $\mathrm{H}^{\mathrm{a}}$ (ii) is not rejected, which is consistent with the preliminary results reported in Table 2.In a similar manner, regression (7) (used in testing $\mathrm{H} 1^{\mathrm{a}}$ (iii)), reports the coefficient estimates of the determinants for the non-cross-listed offers for the full period. Here, the coefficient estimate of the dummy variable DumPerBill is also not significant $(0.0147$, p-value of 0.5883). Thus, $\mathrm{H} 1^{\mathrm{a}}$ (iii) is also not rejected. In other words, these results show 
the market reaction to offer announcements is also not significantly different between the pre- and post-Bill periods for cross-listed and non-cross-listed firms, respectively.

The testing of the auxiliary hypotheses $\mathrm{H}^{\mathrm{b}}(\mathrm{i})$ and $\mathrm{H} 1^{\mathrm{b}}(\mathrm{ii})$ is as follows. Regression (2) reports the coefficient estimates of the determinants of CAAR in which the dummy variable DumPostBill replaces the dummy variable DumPerBill to allow for interactions with the determinants. Similarly, in regression (3), DumPreBill replaces DumPerBill for the same purpose. The coefficient estimates reported in regressions (2) and (3) allow identifying the differential impact (if any) that each determinant has on CAAR for the pre- and post-Bill periods, respectively. The coefficient estimates of each independent variable reported in regression (2) show the effect that each determinant has on CAAR for the preBill period only.

For instance, in regression (2) the negative and not significant coefficient estimate of the cross-listing dummy (DumCross) of -0.0034 (p-value of 0.7817 ) shows cross-listed offers have no effect on CAAR for the pre-Bill period. This implies that the market reaction to offer announcements is not different between cross-listed and non-cross-listed firms for the pre-Bill period. Thus, $\mathrm{H} 1^{\mathrm{b}}(\mathrm{i})$ is not rejected. On the other hand, the sensitivity shift of DumCross for the post-Bill period (i.e., DumCross $*$ DumPostBill) is also not significant $(0.0165$, p-value of 0.3891). Similarly, the net effect value of $0.0131(-0.0034+0.0165)$, -which is the coefficient estimate of DumCross for the post-Bill period- is not significant (p-value of 0.3691 ) as reported in regression (3). This implies the market reaction to offer announcements is also not different between crosslisted and non-cross-listed firms for the post-Bill period. Thus, hypothesis $\mathrm{H} 1^{\mathrm{b}}$ (ii) is also not rejected. In other words, the market reaction to offers announcements between cross-listed firms and non-cross-listed firms is not significantly different for the pre- and post-Bill periods, respectively.

On the other hand, the signed coefficient estimates of control variables TO[+], D2 [+] (capital investment), RUNUP [+], RELOFFER [-], CHTRADES [-], DumGLO [-], DumOAO[+] and D4[+] (debt reduction) display the predicted signs, except BRUNNERS[-].The estimated signed coefficient of the dummy years (unreported) that are significant are 2005 [-], 2008[+], and 2009[-]; all at the 0.10 level. In short, hypotheses $\mathrm{H} 1 \mathrm{a}(\mathrm{i}), \mathrm{H} 1^{\mathrm{a}}(\mathrm{ii}), \mathrm{H} 1^{\mathrm{a}}(\mathrm{iii}), \mathrm{H} 1^{\mathrm{b}}(\mathrm{i})$ and $\mathrm{H} 1^{\mathrm{b}}$ (ii) are not rejected, after controlling for offer and firm characteristics. This is consistent with the preliminary results reported in Table 2.

\section{Testing of H2 Auxiliary Hypotheses}

This section examines the three $\mathrm{H} 2$ auxiliary hypotheses using cross-sectional regression model (2). Regressions (1) to (3) of Table 5 display the coefficient estimates for the determinants of the overall offers, for the entire, pre- and postBill periods, respectively. Regression (1) shows the coefficient estimate of marketed underwritten offers is negative and significant for the entire time period 1999-2011 (-0.0218, p-value of 0.0179). This shows the market reaction to marketed underwritten offers is less positive than bought deals for the entire 
period. Regression (2) of Table 5 shows the coefficient estimate of marketed underwritten offers (DumMUO) is not significant (-0.0127, p-value of 0.3466) for the pre-Bill period. This means the market reaction to marketed offers is not significantly different from bought deals for the pre-Bill period -for the overall SEOs. Thus, H2(i) is not rejected. On the other hand, regression (3) shows the coefficient estimate of DumMUO is marginally significant $(-0.0250, \mathrm{p}$-value of $0.0627)$. This suggests marketed offers display slightly more negative market reaction than bought deals for the post-Bill period only. Thus, hypothesis H2(i) is rejected at the 10 percent level for the post-Bill period only.

Regressions (4) to (6) of Table 5 report coefficient estimates for the determinants of cross-listed offers for the entire, pre- and post-Bill periods, respectively. Regression (4) shows the estimated coefficient of DumMUO is negative and non-significant (-0.0082, p-value of 0.6018). This shows the market reaction to marketed offers is not significantly different from bought deals for the entire sample period. Similar findings occur for the pre- and post-Bill periods, that is, the coefficient estimates of DumMUO for the pre- Bill period $(0.0005)$ and post-Bill period (-0.0290) are not significant. This reveals the market reaction to marketed underwritten offers is not significantly different from bought deals for the pre- and post-Bill periods, respectively. Thus, hypothesis H2(ii) is not rejected, which is consistent with p-value tests reported in Table 3. The control variables that are significant such as DumGLO, DumOAO and RELOFFER display the sign of the estimated coefficients as predicted. The signed coefficient estimates of the dummy years (unreported) that are significant are 2003 [-] (at 0.10 level), 2005 [-] (at 0.05 level, and 2009[-] (at 0.05 level). The coefficient estimate of global offers (DumGLO) is negative and marginally significant (regression 5) in the pre-Bill period only. Rubalcava (2012b) finds global offerings of cross-listed firms are significant at 0.05 level for the pre-SOX period (1995-2002) only. Thus, the three-year period from 2003 to 2005 -from the Bill 198 decree to its effective application- contributed to attenuate the negative effect on the market reaction of global offer announcements, which disappeared after the post-Bill period.

Regressions (7) to (9) report regression results of non-cross-listed offers for the full, pre- and post-Bill periods, respectively. Regression (7) shows the coefficient estimate of DumMUO is negative and significant. This suggests the market reaction to marketed offers is less positive than bought deals for the entire sample period. On the other hand, regression (8) shows the estimated coefficient of DumMUO is not significant for the pre-Bill period $(-0.0181$, pvalue of 0.3755 ). However, it is negative and marginally significant in the postBill period (-0.0313, p-value of 0.0634). These results show the market reaction to marketed underwritten offers is less positive than bought deals for the post-Bill period only. Thus, hypothesis H2(iii) is marginally rejected for the post-Bill period only, which is consistent with the p-value test in Table 3 . The control variables that are significant such as D2 (capital investment), RUNUP, and DumOAO display the predicted sign of their estimated coefficients except BRUNNERS, which is negative. The coefficient estimate of the dummy year $2008[+]$ (unreported) is the only that is significant (at 0.05 level). 
Table 5. Determinants of Announcement Date Abnormal Returns for the SEOs of Canadian Firms for the Pre and Post Bill 198 Time Periods

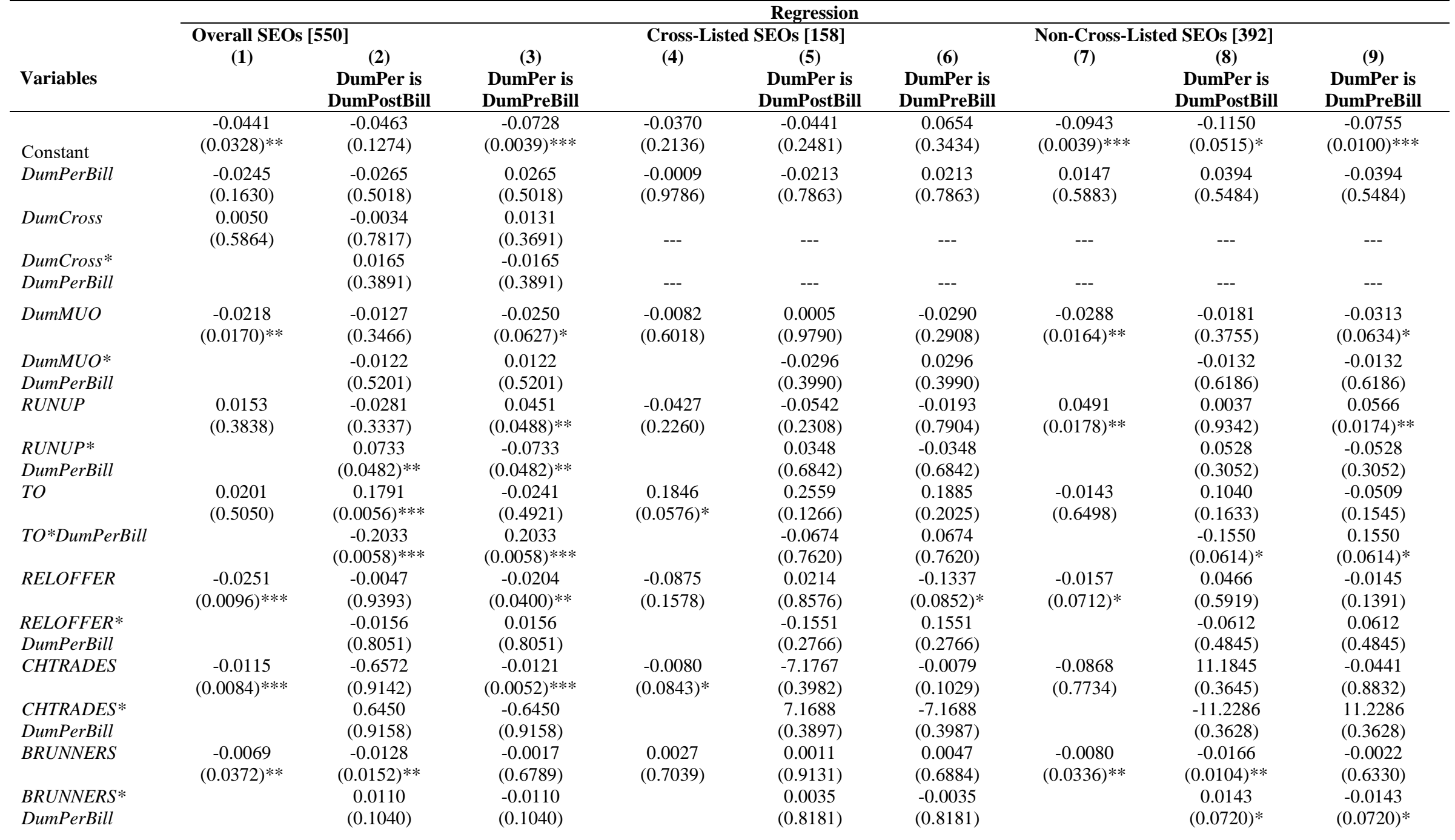


Athens Journal of Business and Economics

January 2018

\begin{tabular}{|c|c|c|c|c|c|c|c|c|c|}
\hline \multirow[t]{2}{*}{ DumGLO } & \multirow{2}{*}{$\begin{array}{c}-0.0286 \\
(0.0237)^{* *}\end{array}$} & -0.0317 & -0.0345 & \multirow{3}{*}{$\begin{array}{c}-0.0367 \\
(0.0224)^{* *}\end{array}$} & \multirow{3}{*}{$\begin{array}{c}-0.0438 \\
(0.0570)^{*} \\
0.0234\end{array}$} & -0.0204 & \multirow[b]{2}{*}{----} & \multirow[b]{2}{*}{---} & \multirow[b]{2}{*}{---} \\
\hline & & $(0.1139)$ & $(0.0564)^{*}$ & & & $(0.4374)$ & & & \\
\hline DumGLO* & & -0.0028 & 0.0028 & & & -0.0234 & & & \\
\hline DumPerBill & & $(0.9159)$ & $(0.9159)$ & & $(0.5019)$ & $(0.5019)$ & --- & --- & --- \\
\hline \multirow[t]{2}{*}{ DUmOAO } & 0.0239 & 0.0166 & 0.0248 & 0.0398 & 0.0470 & 0.0309 & 0.0179 & -0.0024 & 0.0225 \\
\hline & $(0.0003) * * *$ & $(0.1945)$ & $(0.0014) * * *$ & $(0.0027)^{* * *}$ & $(0.0176) * *$ & $(0.1372)$ & $(0.0206)^{* *}$ & $(0.8985)$ & $(0.0079) * * *$ \\
\hline DumOAO* & & 0.0082 & -0.0082 & & -0.0160 & 0.0160 & & 0.0249 & -0.0249 \\
\hline DumPerBill & & $(0.5813)$ & $(0.5813)$ & & $(0.5735)$ & $(0.5735)$ & & $0.2276)$ & $(0.2276)$ \\
\hline \multirow{2}{*}{ DI } & 0.0242 & 0.0364 & 0.0107 & 0.03895) & 0.0357 & 0.0501 & 0.0197 & 0.0646 & -0.0092 \\
\hline & $(0.1309)$ & $(0.1209)$ & $(0.6408)$ & $(0.1197)$ & $(0.2568)$ & $(0.3196)$ & $(0.3582)$ & $(0.1648)$ & $(0.7269)$ \\
\hline \multirow[t]{2}{*}{ D1*DumPerBill } & & -0.0257 & 0.0257 & & 0.0144 & -0.0144 & & -0.0738 & 0.0738 \\
\hline & & $(0.4336)$ & $(0.4336)$ & & $(0.8078)$ & $(0.8078)$ & & $(0.1675)$ & $(0.1675)$ \\
\hline \multirow[t]{2}{*}{ D2 } & 0.0284 & 0.0458 & 0.0234 & 0.0222 & 0.0291 & 0.0219 & 0.0369 & 0.0876 & 0.0215 \\
\hline & $(0.0455) * *$ & $(0.0433) * *$ & $(0.2212)$ & $(0.3182)$ & $(0.3356)$ & $(0.6110)$ & $(0.0522) *$ & $(0.0475)^{* *}$ & $(0.3194)$ \\
\hline \multirow[t]{2}{*}{ D2*DumPerBill } & & -0.0223 & 0.0223 & & -0.0071 & 0.0071 & & -0.0660 & 0.0660 \\
\hline & & $(0.4499)$ & $(0.4499)$ & & $(0.8916)$ & $(0.8916)$ & & $(0.1793)$ & $(0.1793)$ \\
\hline \multirow[t]{2}{*}{ D3 } & 0.0301 & 0.0305 & 0.0339 & 0.0167 & 0.0142 & 0.0265 & 0.0398 & 0.0752 & 0.0283 \\
\hline & $(0.0639) *$ & $(0.2294)$ & $(0.1246)$ & $(0.5090)$ & (0.6643) & $(0.5907)$ & $(0.0683)^{*}$ & $(0.1311)$ & $(0.4008)$ \\
\hline \multirow[t]{2}{*}{ D3*DumPerBill } & & 0.0033 & -0.0033 & & 0.0123 & -0.0123 & & -0.0468 & 0.0283 \\
\hline & & $(0.9198)$ & $(0.9198)$ & & $(0.8350)$ & $(0.8350)$ & & $(0.4008)$ & $(0.2593)$ \\
\hline \multirow[t]{2}{*}{ D4 } & 0.0326 & 0.0344 & 0.0354 & 0.0455 & 0.0489 & 0.0469 & 0.0378 & 0.0672 & 0.0300 \\
\hline & $(0.0386)^{* *}$ & $(0.1690)$ & $(0.0946)^{*}$ & $(0.0945)^{*}$ & $(0.1720)$ & $(0.3748)$ & $(0.0652)^{*}$ & $(0.1555)$ & $(0.2021)$ \\
\hline \multirow[t]{2}{*}{ D4*DumPerBill } & & 0.0010 & -0.0010 & & -0.0019 & 0.0019 & & -0.0371 & 0.0371 \\
\hline & & $(0.9751)$ & $(0.9751)$ & & $(0.9751)$ & $(0.9751)$ & & $(0.4812)$ & $(0.4812)$ \\
\hline Dummy Years & Yes & Yes & Yes & Yes & Yes & Yes & Yes & Yes & Yes \\
\hline $\mathrm{R}^{2} \mathrm{Adj}$ & 0.091 & 0.105 & 0.105 & 0.221 & 0.174 & 0.174 & 0.062 & 0.082 & 0.082 \\
\hline F (Prob) & 0.0000 & 0.000 & 0.000 & 0.000 & 0.004 & 0.004 & 0.001 & 0.000 & 0.000 \\
\hline
\end{tabular}

Source: Own Calculation on the basis of FP advisor, SEDAR, and CFMRC data 
Overall, the empirical results show the passage of Bill 198 did not have any significant impact on the market reaction to seasoned equity offerings of Canadian issuers, including cross-listed and non-cross listed issuers, after conditioning on firm and offer characteristics. However, when distinguishing offers by underwriting method, i.e., marketed underwritten and bought deals, the market reaction is more negative for marketed underwritten offers during the post-Bill period only -mostly for non-cross-listed issuers. This may explain why marketed underwritten offers have declined drastically as the underwriting choice of seasoned equity offerings in the last few years.

\section{Conclusions}

The purpose of this paper is to examine the financial impact of Canadian Bill 198 on the market reaction to seasoned equity offerings of publicly traded Canadian firms -those cross-listed on U.S. major exchanges and those listed on the TSX only (non-cross-listed). Canadian Bill 198 is legislation equivalent to the U.S. Sarbanes-Oxley Act of 2002 and is focused on fostering transparent and reliable financial information of publicly traded companies. Bill 198 was enacted in October 2002 and became effective in December 2005.Canadian Bill 198 and SOX include several provisions of good corporate governance to protect investors against illegal and unethical corporate conduct. Firm-specific events that may have a material impact on the profitability of companies should be disclosed properly according to both pieces of legislation. One important firm event is announcing a seasoned equity offering, in which the market reaction is around -2 percent on average, representing an important indirect issuing cost for companies. This study examine whether investors' reaction to the announcement of seasoned equity offerings of Canadian firms has significantly changed after Bill 198 became effective in 2005.

The sample includes 550 seasoned equity offerings by Canadian issuers cross-listed on the U.S. and not cross-listed- from 1999 to 2011. The pre-Bill period (1999-2005) includes 179 offers and the post-Bill period (2006-2011) includes 371 offers. Cross- and non-cross-listed firms are matched using the 4digit SIC industry code. An asset pricing model examines the market reaction (abnormal return) around the announcement to offer announcements. A crosssectional-regression model tests the relationship on the cumulative abnormal returns (market reaction) of SEOs with the expected determinants for the entire, cross-listed, and non-cross-listed offers, respectively, for the pre- and post-Bill periods.

The empirical results show the market reaction to all offer announcements is not different between the pre- and post-Bill periods. When distinguishing offers by cross-listed and matched non-cross-listed firms, no significant difference on the market reaction occurs between the pre- and post-Bill periods, after controlling for offer and firm characteristics. This implies Bill 198 has not had a significant impact in issuance costs for firms. On the other hand, when distinguishing offers by underwriting method (marketed underwritten versus 
bought deals), the market reaction is less positive for marketed underwritten offers than bought deals for the post-Bill period only, mostly for non-crosslisted firms. A feasible explanation is found by Pandes (2010) who argues the less positive market reaction for marketed underwritten offers of Canadian issuers is because they are not certified by underwriters unlike bought deals which they are. This might explain why marketed underwritten offers have declined significantly in the last years.

Policy implications of the study are as follows. Since Canadian Bill 198 did not have major impact on the market reaction to seasoned equity offerings of Canadian issuers, it appears the three-year period-before Bill 198 became effective in 2005 has allowed investors, exchange traded Canadian companies, investors and investment banks enough time to prepare to the new law. That is, they have adjusted for important firm-specific events including announcing seasoned equity offerings. Thus, the gradual approach followed by Canadian regulators in implementing Bill 198 has been a wise decision by reducing market uncertainty. This contrasts with the SOX legislation carried out shortly after its enactment, where many errors have occurred in its implementation (Gray 2005).

Some limitations of the study and suggestion for future research are as follows. It does not include data beyond 2011 to enhance the robustness of the results. Also, it does not account for determinants that may explain the market reaction to offer announcements such as insider ownership and financial institution shareholding. A future research venue is to explore whether the findings of this study can be generalizable to other countries that have implemented similar legislations such as SOX and Canadian Bill 198.

\section{Acknowledgements}

Financial support from the Dean's Research Grant Fund of the Faculty of Business Administration and the SSHRC-President's Fund of the University of Regina are gratefully acknowledged. I thank the anonymous referees for their feedback. I also appreciate the comments of conference participants at the $15^{\text {th }}$ Annual International Conference on Finance held in Athens, Greece, and at the 2016 Symposium "Cross-Country Issues on Credit, Banking, Asset Pricing, and Market Liquidity" held in Taiyuan, China, particularly those by Keith Anderson. Special gratitude to Emmanuel Emenike Williams for valuable research assistance. The usual disclaimer applies.

\section{References}

Amoako-Adu B and Baulkaran V (2008) The effects of the Sarbanes-Oxley Act and Canadian equivalent, Bill 198/CSA rules, on Canadian cross-listed stocks. Unpublished Manuscript, Wilfrid Laurier University.

Ben-Ishai S (2008) Sarbanes-Oxley five years later: A Canadian perspective. Loyola University Chicago Law Journal 39(3): 469-492. 
Bortolotti B, Megginson W, Smart SB (2008)The rise of accelerated seasoned equity underwritings. Journal of Applied Corporate Finance 20(3): 35-57.

Bozec R, Dia M, Bozec Y (2010) Governance-performance relationship: A reexamination using technical efficiency measures. British Journal of Management 21: 684-700.

Bozec R, Dia M (2012) Convergence of corporate governance practices in the post-Enron period: behavioral transformation or box-checking exercise? Corporate Governance: The International Journal of Business in Society 12(2): 243-256.

Bozec R, Dia M and Bozec Y (2013) Corporate ownership and governance practices in Canada: a longitudinal study. International Journal of Corporate Governance 4(1): 51-73

Bris A, Cantale S, Nishiotis G (2007) A breakdown of the evaluation effects of international cross-listing. European Financial Management 13(3): 498-530.

Easley DN, Kieffer M, O'Hara Mand Paperman JB(1996) Liquidity, information, and infrequently traded stocks. Journal of Finance 51(4): 1405-1437.

Eckbo BE, Masulis RW (1995) Seasoned equity offerings: A survey. In Jarrow RA, Maksimovic V, and Ziemba WT (Eds.), Finance. (pp. 1017-1072) Elsevier/ North-Holland, Handbooks in Operations Research and Management Science Series.

Eckbo BE, Masulis RW, Norly $\Phi$ (2007) Security offerings. In Eckbo BE (Ed.), Handbook of corporate finance: empirical corporate finance. (pp. 233-373) Elsevier/ North-Holland Handbook of Finance Series.

Emerson HG, Clarke GA (2003) Bill 198 and Ontario's Securities Act: Giving investors and the OSC added muscle. Unpublished Manuscript. Retrieved from http://www.fas ken.com/files/Publication/4348346f-28f6-4007-b37f-6fe91ca7ff 38/Presentation/ PublicationAttachment/28e70b5f-89f3-4684-a7ba-7e08688c d5c0/ BILL198.PDF.

Foerster SR and Karoli GA (1999) The effects of market segmentation and investor recognition an asset prices: Evidence from foreign stocks listing in the United States. Journal of Finance 54: 981-1013.

Gray T (2005) Canadian response to the U.S. Sarbanes-Oxley Act of 2002: New directions for corporate governance. Library of Parliament. Retrieved from http:///www.pa rl.gc.ca/content/lop/researchpublications/prb0537-e.htm.

Gunay E and Ursel N (2015) Underwriter competition in accelerated seasoned equity offerings: Evidence from Canada. Journal of International Financial Markets, Institutions and Money 34: 94-110.

Hossain AT (2013) Impact of Canadian SOX on Canadian acquisitions. Journal of Accounting and Finance 13(5): 11-25

Jeon JQ and Ligon, JA (2011)The role of co-managers in reducing flotation cost: Evidence from seasoned equity offerings. Journal of Banking \& Finance 35: 1041-1056.

Jiang L, KryzanowskiL (1998) Trading activity, quoted liquidity and stock volatility. Multinational Finance Journal 1(3): 199-227.

Li X (2011) An examination of the impact of the Sarbanes-Oxley Act on cross-listed foreign private issuers and the legal bonding hypothesis. Unpublished manuscript. Retrieved from http://papers.ssrn.com/sol3/papers.cfm?abstract_id=95243.

Litvak K (2007) The effect of the Sarbanes-Oxley act on non-US companies crosslisted in the US. Journal of Corporate Finance 13: 195-228.

Litvak K (2008) The long-term effect of the Sarbanes-Oxley Act on cross-listing premia. European Financial Management 14: 875-920.

Loderer C, Cooney JW, Van Drunnen LD (1991)The price elasticity of demand for common stock. Journal of Finance 46(2): 621-651. 
Mahoney LS, Thorne L (2013) The evolution in CSR reporting: A longitudinal study of Canadian firms. Research on Professional Responsibility and Ethics in Accounting 17: 79-96.

Myers SC, Majluf NS (1984) Corporate financing and investment decisions when firms have information that investors do not have. Journal of Financial Economics 13: $187-221$.

Pandes JA (2010) Bought deals: The value of underwriter certification in seasoned equity offerings. Journal of Banking and Finance 34: 1576-1589.

Ritter J (1998) Initial public offerings. Contemporary Finance Digest 2: 5-30.

Rubalcava A (2012a) The Sarbanes-Oxley: research potential of similar regulations in other countries. Journal of Business \& Financial Affairs 1(3).

Rubalcava A (2012b) Valuation effects of the Sarbanes-Oxley Act: Evidence from seasoned equity offerings by Canadian cross-listed firms. International Journal of Business, Accounting, and Finance 6(1): 75-91.

Rubalcava A (2015) Impact of Sarbanes-Oxley on seasoned equity offerings by Canadian cross-listed firms: Evidence from bought deals vs. firm commitment. International Journal of Business and Finance Research 9(1): 63-72. 
